\title{
LA POSMODERNIDAD. NUEVO RÉGIMEN DE VERDAD, VIOLENCIA METAFÍSICA Y FIN DE LOS METARRELATOS
}

\author{
Adolfo Vásquez Rocca ${ }^{1}$
}

Universidad Católica de Valparaíso

Universidad Complutense de Madrid

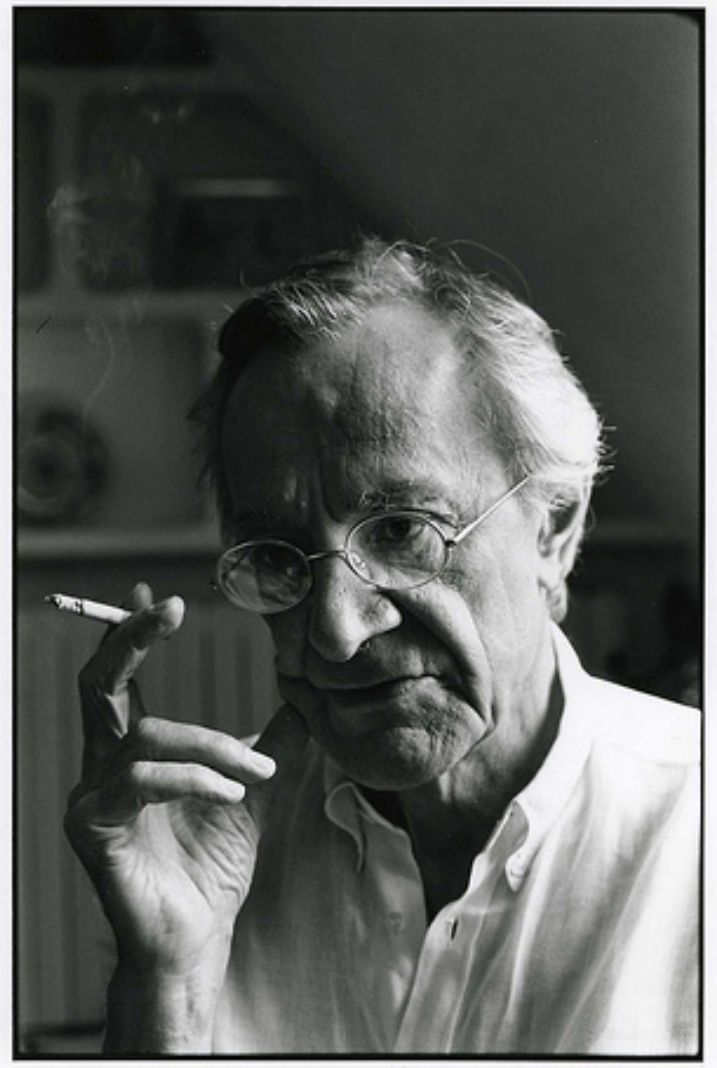

1 Doctor en Filosofía por la Pontificia Universidad Católica de Valparaíso; Postgrado Universidad Complutense de Madrid, Departamento de Filosofía IV. Profesor de Postgrado del Instituto de Filosofía de la Pontificia Universidad Católica de Valparaíso; Profesor de Antropología y Estética en el Departamento de Artes y Humanidades de la Universidad Andrés Bello UNAB. - Miembro del Consejo Editorial Internacional de la 'Fundación Ética Mundial' de México. Director del Consejo Consultivo Internacional de 'Konvergencias', Revista de Filosofía y Culturas en Diálogo, Argentina. Miembro del Conselho Editorial da Humanidades em Revista, Universidade Regional do Noroeste do Estado do Rio Grande do Sul, Brasil. -Director de Revista Observaciones Filosóficas. Profesor visitante en la Maestría en Filosofía de la Benemérita Universidad Autónoma de Puebla. - Profesor visitante Florida Christian University USA y Profesor Asociado al Grupo Theoria -Proyecto europeo de Investigaciones de Postgrado- UCM. Académico Investigador de la Vicerrectoría de Investigación y Postgrado, Universidad Andrés Bello. Artista conceptual. Ha publicado el Libro: Peter Sloterdijk; Esferas, helada cósmica y políticas de climatización, Colección Novatores, № 28, Editorial de la Institución Alfons el Magnànim (IAM), Valencia, España, 2008. Invitado especial a la International Conference de la Trienal de Arquitectura de Lisboa | Lisbon Architecture Triennale 2011 
Resumen.- He aquí una breves notas en torno a la noción de posmodernidad. Un texto introductorio que intenta dar luz sobre algunas tópicos que se entrecruzan y problematizan a un poco más de 30 años de la publicación de La condición posmoderna de Jean-François Lyotard. Esta condición es -según el decir del propio Lyotard-condición del saber en las sociedades más desarrolladas, particularmente en el continente americano, en pluma de sociólogos y críticos. Lo posmoderno no es "lo contrario" de lo moderno, sino su rebasamiento. Es la modernidad misma que en su autocumplimiento invierte sus modalidades y efectos culturales. El descrédito de la razón, la ciencia y la técnica no ha surgido de una "negación simple" de estas, sino de su concreción histórico-factual, de su realización. La posmodernidad designa el estado de la cultura después de las transformaciones que han afectado a las reglas de juego de la ciencia, de la literatura y de las artes a partir del siglo XIX. Aquí se situarán esas transformaciones con relación a la crisis de los grandes relatos. Se tiene por "posmoderna" la incredulidad con respecto a los metarrelatos. Ésta es, sin duda, un efecto del progreso de las ciencias; pero ese progreso, a su vez, la presupone. Al desuso del dispositivo metanarrativo de legitimación corresponde especialmente la crisis de la filosofía metafísica, y la de la institución universitaria que dependía de ella.

Palabras cl ave.- Posmodernidad, relato, razón, fragmento, narración, momento, totalidad, proyecto, estética, dialéctica, discurso, postmodernidad, simulacro, ética.

\begin{abstract}
Here is a brief notes about the notion of postmodernity. An introductory text that attempts to shed light on some topics that are intertwined and problematize a little over 30 years since the publication of La Condition posmoderna of Jean-François Lyotard. This condition is, according to Lyotard's own say-condition of knowledge in more developed societies, particularly in the Americas, in pen and critical sociologists. The postmodern is not "opposite" of the modern, but its excess. It is modernity itself that in its self reversed their modalities and cultural effects. The discrediting of reason, science and technology has emerged from a "mere denial" of these, but its factual and historical specificity of their realization. Postmodernism means the state of culture after the changes that have affected the rules of the game of science, literature and art from the nineteenth century. Here we place these transformations in relation to the crisis of the great stories. It is "postmodern" incredulity about metanarratives. This is undoubtedly an effect of scientific progress but that progress in turn presupposes it. With disuse metanarrative legitimation device responds particularly the crisis of metaphysical philosophy, and of the university depended on it.
\end{abstract}

Keywords.- Postmodern narrative reason, fragment, narrative, time, completeness, design, aesthetic, dialectical, speech, simulation, ethics.

\title{
1.- De la destot alización del mundo a la obsesión epistemológica por los fragmentos.
}

Lo que se denomina "posmodernidad" aparece como una conjunción ecléctica de teorías. Esa amalgama va desde algunos planteamientos nietzscheanos e instintivistas hasta conceptos tomados del Pragmatismo anglosajón hasta pasar por retazos terminológicos heideggerianos, nietszcheanos y existencialistas. Se trata, pues, de un tipo de pensamiento en el que caben temáticas dispersas $\mathrm{y}$, a menudo, conjuntadas sin un hilo teórico claro. 
La posmodernidad no es una época que se halle después de la modernidad como etapa de la historia. El "post" de la posmodernidad, a juicio de Gianni Vattimo2, es "espacial" antes que "temporal". Esto quiere decir que estamos sobre la modernidad. La Posmodernidad no es un tiempo concreto ni de la historia ni del pensamiento, sino que es una condición humana determinada, como insinúa Lyotard en La condición postmoderna3.

El término posmodernidad nace en el domino del arte y es introducido en el campo filosófico hace tres décadas por Jean Lyotard con su trabajo La condición postmoderna4.

Jean-Francois Lyotard explica la Condición postmoderna de nuestra cultura como una emancipación de la razón y de la libertad de la influencia ejercida por los "grandes relatos", los cuales, siendo totalitarios, resultaban nocivos para el ser humano porque buscaban una homogeneización que elimina toda diversidad y pluralidad: "Por eso, la Posmodernidad se presenta como una reivindicación de lo individual y local frente a lo universal. La fragmentación, la babelización, no es ya considerada un mal sino un estado positivo" porque "permite la liberación del individuo, quien despojado de las ilusiones de las utopías centradas en la lucha por un futuro utópico, puede vivir libremente y gozar el presente siguiendo sus inclinaciones y sus gustos".

La posmodernidad, dice Lyotard, es una edad de la cultura. Es la era del conocimiento y la información, los cuales se constituyen en medios de poder; época de desencanto y declinación de los ideales modernos; es el fin, la muerte anunciada de la idea de progreso.

\section{2.- De los grandes relatos a las petites histoires}

El término posmodernidad puede ser identificado, como lo hace Habermas, con las coordenadas de la corriente francesa contemporánea de Bataille a Derrida, pasando por Foucault, con particular atención al movimiento de la deconstrucción de indudable actualidad y notoria resonancia en la intelectualidad local. Las oposiciones binarias que rigen en Occidente -sujeto/objeto, apariencia/realidad, voz/escritura, etc. construyen una jerarquía de valores nada inocente, que busca garantizar la verdad y sirve para excluir y devaluar los términos inferiores de la oposición. Metafísica binaria que privilegia la realidad y no la apariencia, el hablar y no el escribir, la razón y no la naturaleza, al hombre y no a la mujer. Hace falta una deconstrucción completa de la filosofía moderna y una nueva práctica filosófica.

La era moderna nació con el establecimiento de la subjetividad5 como principio constructivo de la totalidad. No obstante, la subjetividad es un efecto de los discursos o

2 VATTIMO, Gianni, El fin de la modernidad. Nihilismo y hermenéutica en la cultura posmoderna / La fine della modernità (1985); Milán, Garzanti.

3 LYOTARD, Jean-François, La condición postmoderna. Madrid: Cátedra S.A. 1987. Originalmente: La Condition postmoderne: Rapport sur le savoir, Editions de Minuit, París, 1979.

4 LYOTARD, Jean-François, La condición postmoderna. Madrid: Cátedra S.A. 1987. Originalmente: La Condition postmoderne: Rapport sur le savoir, Editions de Minuit, París, 1979.

5 HABERMAS, Jürgen, El pensamiento postmetafisico, Editorial Taurus, Madrid, 1990, p. 85. 
textos en los que estamos situados6. Al hacerse cargo de lo anterior, se puede entender por qué el mundo postmoderno se caracteriza por una multiplicidad de juegos de lenguaje que compiten entre sí, pero tal que ninguno puede reclamar la legitimidad definitiva de su forma de mostrar el mundo.

Con la deslegitimación de la racionalidad totalizadora procede lo que ha venido en llamarse el fin de la historia. La posmodernidad revela que la razón ha sido sólo una narrativa entre otras en la historia; una gran narrativa, sin duda, pero una de tantas. Estamos en presencia de la muerte de los metarrelatos, en la que la razón y su sujeto como detentador de la unidad y la totalidad- vuelan en pedazos. Si se mira con más detenimiento, se trata de un movimiento de deconstrucción del cogito y de las utopías de unidad. Aquí debe subrayarse el irreductible carácter local de todo discurso, acuerdo y legitimación. Esto nos instala al margen del discurso de la tradición literaria (estética) occidental. Tal vez de ahí provenga la vitalidad de los engendros del discurso periférico, en Los Margenes de la Filosofía7 como dirá Derrida.

La destotalización del mundo moderno exige eliminar la nostalgia del todo y la unidad. Como características de lo que Foucault ha denominado la episteme8 posmoderna podrían mencionarse las siguientes: deconstrucción, descentración, diseminación, discontinuidad, dispersión. Estos términos expresan el rechazo del cogito que se había convertido en algo propio y característico de la filosofía occidental, con lo cual surge una "obsesión epistemológica" por los fragmentos.

La ruptura con la razón totalizadora supone el abandono de los grands récits, es decir, de las grandes narraciones, del discurso con pretensiones de universalidad y el retorno de las petites histoires. Tras el fin de los grandes proyectos aparece una diversidad de pequeños proyectos que alientan modestas pretensiones. Aquí se insiste en el irreductible pluralismo de los juegos de lenguaje, acentuando el carácter local de todo discurso, y la imposibilidad de un comienzo absoluto en la historia de la razón. Ya no existe un lenguaje general, sino multiplicidad de discursos. $Y$ ha perdido credibilidad la idea de un discurso, consenso, historia o progreso en singular: en su lugar aparece una pluralidad de ámbitos de discurso y narraciones.

Además de señalar que la desmitologización de los grandes relatos es lo característico de la posmodernidad, es necesario aclarar que estos metarrelatos no son propiamente mitos, en el sentido de fábulas. Ciertamente tienen por fin legitimar las instituciones y prácticas sociales y políticas, las legislaciones, las éticas. Pero, a diferencia de los mitos, no buscan

6 El dominio del sujeto se ve subvertido por el hecho de que siempre nos encontramos situados de antemano en lenguajes que no hemos inventado (donde la Razón es equiparada a una subjetividad dominante, a una voluntad de poder) y que necesitamos para poder hablar de nosotros mismos y del mundo.

7 DERRIDA, Jacques, Márgenes de la filosofía. Madrid, Cátedra, 1988

8 "La épistémè no es una teoría general de toda ciencia posible o de todo enunciado científico posible, sino la normatividad interna de las diferentes actividades científicas tal como han sido practicadas y de lo que las ha hecho históricamente posibles". Cf. FOUCAULT, Michel, "La vie: L'expèrience et la science", en Revue de Métaphysique et de Morale, 1 enero-marzo de 1985, R. 10.

"En una cultura en un momento dado, nunca hay más que una sola épistémè, que define las condiciones de posibilidad de todo saber. Sea el que se manifiesta en una teoría o aquel que está silenciosamente envuelto en una práctica". FOUCAULT, Michel, Las palabras y las cosas, Ed. Gallimard, París, 1966, p. 179. 
esta legitimación en un acto fundador original, sino en un futuro por conseguir, en una idea por realizar. De ahí que la modernidad sea un proyecto.

Los metarrelatos son las verdades supuestamente universales, últimas o absolutas, empleadas para legitimar proyectos políticos o científicos. Así por ejemplo, la emancipación de la humanidad a través de la de los obreros (Marx), la creación de la riqueza (Adam Smith), la evolución de la vida (Darwin), la dominación de lo inconsciente (Freud), etc.

El mundo postmoderno ha desechado los metarrelatos. El metarrelato es la justificación general de toda la realidad, es decir, la dotación de sentido a toda la realidad. Ninguna justificación puede alcanzar a cubrir toda la realidad, ya que necesariamente caerá en alguna paradoja lógica o alguna insuficiencia en la construcción (especialmente en la completitud o en la coherencia) y que desdicen sus propias pretensiones onmiabarcantes. El hombre postmoderno no cree ya los metarrelatos, el hombre postmoderno no dirige la totalidad de su vida conforme a un solo relato, porque la existencia humana se ha vuelto tan enormemente compleja que cada región existencial del ser humano tiene que ser justificada por un relato propio, por lo que los pensadores postmodernos llaman microrrelatos.

El microrrelato tiene una diferencia de dimensión respecto del metarrelato, pero esta diferencia es fundamental, ya que sólo pretende dar sentido a una parte delimitada de la realidad y de la existencia. Cada uno de nosotros tiene diferentes microrrelatos, probablemente desgajados de metarrelatos, que entre ellos pueden ser contradictorios, pero el ser humano postmoderno no vive esta contradicción porque él mismo ha deslindado cada una de esta esfera hasta convertirlas en fragmentos. El hombre postmoderno vive la vida como un conjunto de fragmentos independientes entre sí, pasando de unas posiciones a otras sin ningún sentimiento de contradicción interna, puesto éste entiende que no tiene nada que ver una cosa con otra. Pero esto no quiere decir que los microrrelatos no sean cambiables sin mayor esfuerzo, ya que los microrrelatos responden al criterio fundamental de utilidad, esto es, son de tipo pragmáticos.

Ahora bien, si no hay metarrelatos tampoco hay utopías. La única utopía posible -si acaso pudiera todavía haber una- es la huida del mundo y de la sociedad y por la conformación del espacio utópico en el seno de la intimidad, con determinados elementos degradados de las tradiciones orientales, de los los nuevos orientalismos. Es una utopía fragmentada para un mundo fragmentado, una religión muy propia de la Posmodernidad, sin sacrificios y sin privaciones.

¿En qué punto nos encontramos ahora? Sin duda en el dominio de la interpretación y la sobreinterpretación. Las interpretaciones dotan de sentido a los hechos. La interpretación es una condición necesaria para que podamos conocer la realidad, para que nos podamos relacionar con ella. La interpretación cuaja en la tradición y es el conocimiento de nuestras formas de interpretación el objeto de la ciencia central de la Posmodernidad: la Hermenéutica. La Hermenéutica tiene sus orígenes en los principios del conocimiento humano, no en vano Aristóteles escribe una tratado sobre la interpretación. Con 
Gadamer $^{9}$ la Hermenéutica cobra un nuevo giro, ya no pretende aprehender el verdadero y único sentido del texto, sino manifestar las diversas interpretaciones del texto y las diversas formas de interpretar. Hemos aludido por primera vez a un elemento fundamental del pensamiento postmoderno: el texto.

En la posmodernidad, si la entendemos como Filosofía del Lenguaje o Teoría Literaria el texto se independiza del autor hasta tal punto de que el autor puede ser obviado. En la posmodernidad hay dos tendencias muy marcadas y contradictorias sobre la autoría, la que la desprecia por centrarse únicamente en el texto y la que quiere explicar el texto como trasunto del autor. No cabe hablar propiamente de un autor, pues el autor del texto se ha perdido, como también se ha perdido el ser humano como sujeto, es decir, como director libre de sus acciones.

Gianni Vattimo, por su parte, define el pensamiento posmoderno con claridad: en él lo importante no son los hechos sino sus interpretaciones. Así como el tiempo depende de la posición relativa del observador, la certeza de un hecho no es más que eso, una verdad relativamente interpretada y por lo mismo, incierta. La posmodernidad, por más polifacética que parezca, no significa una ética de carencia de valores en el sentido moral, pues precisamente su mayor influencia se manifiesta en el actual relativismo cultural. La moral posmoderna es una moral que cuestiona el cinismo religioso predominante en la cultura occidental y hace hincapié en una ética basada en la intencionalidad de los actos y la comprensión inter y transcultural de corte secular de los mismos. En este sentido la posmodernidad abre el camino, según Vattimo, a la tolerancia, a la diversidad. Es el paso del pensamiento fuerte, metafísico, de las cosmovisiones filosóficas bien perfiladas, de las creencias verdaderas, al pensamiento débil, a una modalidad de nihilismo débil, a un pasar despreocupado y, por consiguiente, alejado de la acritud existencial.

Vattimo ha elaborado la idea de un pensamiento débil ${ }^{10}$ como portavoz de la sospecha, se trata de un pensamiento eminentemente crítico, no tolera ninguna pretensión totalitaria sobre la realidad, ningún pensamiento que quiere trascender los límites del microrrelato. Detrás de cada intención totalitaria, de cada metarelato como pretensión de interpretación última y definitiva sobre la realidad y el sentido del mundo se esconde un interés del poder, de un poder manifiesto u oculto, que, a través del lenguaje ontologizado y ontologizante -metafísico y/o teológico, quiere someter la realidad a una visión univoca y normativa, anulando y vaciando la potencialidad humana de hacer y crear mundos.

Debemos situar el punto de partida de este paradigma - del asalto a la razón - en la filosofía de Nietzsche, aunque ubicado poco antes, contemporáneo al lluminismo, debemos hacer justicia al Romanticismo,corriente continental que inició la crítica de la Modernidad poniendo énfasis, ya no en la razón, sino en la intuición, la emoción, la aventura, un retorno a lo primitivo, el culto al héroe, a la naturaleza y a la vida, y por sobre todas las cosas una vuelta al panteísmo. Nietzsche se encargará de revitalizar estos motivos casi un siglo más tarde, imprimiéndole su sello propio, una filosofía cuyos rasgos esenciales han de ser el individualismo, un relativismo gnoseológico y moral, vitalismo, nihilismo y ateísmo, todo esto sobre un telón de fondo irracionalista.

9 GADAMER, Hans-Georg, El giro hermenéutico, Madrid, Cátedra, 1990.

10 VATTIMO, Gianni, El pensamiento débil / Il pensiero debole (1983); editado por G. Vattimo y P. A. Rovatti, Milán 
Gianni Vattimo tiene razón cuando ve en Nietzsche el origen del postmodernismo, pues él fue el primero en mostrar el agotamiento del espíritu moderno en el 'epigonismo'. De manera más amplia, Nietzsche es quien mejor representa la obsesión filosófica del Ser perdido, del nihilismo triunfante después de la muerte de Dios.

El postmodernismo aparece, pues, como resultado de un gran movimiento de deslegitimación llevado a cabo por la modernidad europea, del cual la filosofía de Nietzsche sería un documento temprano y fundamental.

La posmodernidad puede ser así entendida como una crítica de la razón ilustrada tenida lugar a manos del cinismo contemporáneo. Baste pensar en Sloterdijk y su Crítica de la razón cínica11, donde se reconoce como uno de los rasgos reveladores de la Posmodernidad el anhelo por momentos de gran densidad crítica, aquellos en que los principios lógicos se difuminan, la razón se emancipa y lo apócrifo se hermana con lo oficial, como acontece según Sloterdijk con el nihilismo desde Nietzsche, y aun desde los griegos de la Escuela Cínica.

La ruptura con la razón totalizadora aparece, por un lado como abandono de los grandes relatos -emancipación de la humanidad-, y del fundamentalismo de las legitimaciones definitivas y como crítica de la "totalizadora" ideología sustitutiva que sería la Teoría de Sistemas.

La posmodernidad ha impulsado -al amparo de esta crítica- "un nuevo eclecticismo en la arquitectura, un nuevo realismo y subjetivismo en la pintura y la literatura, y un nuevo tradicionalismo en la música"12. La repercusión de este cambio cultural en la filosofía ha conducido a una manera de pensar que se define a sí misma, según he anticipado, como fragmentaria y pluralista, que se ampara en la destrucción de la unidad del lenguaje operada a través de la filosofía de Nietzsche y Wittgenstein.

Lo específicamente postmoderno son los nuevos contextualismos o eclecticismos. La concepción dominante de la posmodernidad acentúa los procesos de desintegración. Subyace igualmente un rechazo del racionalismo de la modernidad a favor de un juego de signos y fragmentos, de una síntesis de lo dispar, de dobles codificaciones; la sensibilidad característica de la llustración se transforma en el cinismo contemporáneo: pluralidad, multiplicidad y contradicción, duplicidad de sentidos y tensión en lugar de franqueza directa, "así y también asa" en lugar del univoco "o lo uno o lo otro", elementos con doble funcionalidad, cruces en lugar de unicidad clara Un singular "Ni sí ni no, sino todo lo contrario. El último reducto posible para la filosofía" -como señalará Nicanor Parra en su Discurso de Guadalajara13.

Así, con la posmodernidad se dice adiós a la idea de un progreso unilineal, surgiendo una nueva consideración de la simultaneidad, se hace evidente también la imposibilidad de sintetizar formas de vida diferentes, correspondientes a diversos patrones de racionalidad.

11 SLOTERDIJK Peter, Critica de la razón cínica I y II, Ed. Siruela, Madrid, 2004.

12 INNERARITY, Daniel, Dialéctica de la Modernidad, Ediciones Rialp, Madrid, 1990, p. 114.

13 "Ni sí ni no, sino todo lo contrario. El último reducto posible para la filosofía", Discurso de Guadalajara, en "Nicanor PARRA tiene la palabra", Compilación de Jaime Quezada, Editorial Alfaguara, Santiago, 1999. 
La posmodernidad, como proceso de descubrimiento, supone un giro de la conciencia, la cual debe adoptar otro modo de ver, de sentir, de constituirse, ya no de ser, sino de sentir, de hacer. Descubrir la dimensión de la pluralidad supone descubrir también la propia inmersión en lo múltiple.

La Modernidad confundió la razón, entendida como facultad, con una forma de racionalidad concreta. Toda la razón había quedado recluida al ámbito de la razón científica natural y matemática. Ignorado otras formas de racionalidad y de pensamiento, a las que se les consideraba menores o irracionales, especialmente a la racionalidad propia del pensamiento estético y literario.

\section{3.- El crepúsculo del deber, la ética indolora y las 'consignas' cosméticas}

En la cultura posmoderna se acentúa un individualismo extremo, un "proceso de personalización" que apunta la nueva ética permisiva y hedonista: el esfuerzo ya no está de moda, todo lo que supone sujeción o disciplina austera se ha desvalorizado en beneficio del culto al deseo y de su realización inmediata, como si se tratase de llevar a sus últimas consecuencias el diagnóstico de Nietzsche sobre la tendencia moderna a favorecer la "debilidad de voluntad", es decir la anarquía de los impulsos o tendencias y, correlativamente, la pérdida de un centro de gravedad que lo jerarquiza todo: "la pluralidad y la desagregación de los impulsos, la falta de un sistema entre ellos desemboca es una "voluntad débil". Asociaciones libres, espontaneidad creativa, nodirectividad, nuestra cultura de la expresión, pero también nuestra ideología del bienestar estimulan la dispersión en detrimento de la concentración, lo temporal en lugar de lo voluntario, contribuyen al desmenuzamiento del Yo, a la aniquilación de los sistemas psíquicos organizados y sintéticos.

La Posmodernidad es un momento de 'consignas' cosméticas: mantenerse siempre joven, se valoriza el cuerpo y adquieren auge una gran variedad de dietas, gimnasias de distinto tipo, tratamientos revitalizantes y cirugías estéticas.

En la posmodernidad los sucesos pasan, se deslizan. No hay ídolos ni tabúes, tragedias ni apocalipsis, "no hay drama" expresará la versión adolescente postmoderna.

La condición postmoderna es, sin embargo, tan extraña al desencanto, como a la positividad ciega de la deslegitimación. ¿Dónde puede residir la legitimación después de los metarrelatos? El criterio de operatividad es tecnológico, no es pertinente para juzgar lo verdadero y lo justo. ¿El consenso obtenido por discusión, como piensa Habermas? Violenta la heterogeneidad de los juegos de lenguaje. Y la invención siempre se hace en el disentimiento. El saber postmoderno no es solamente el instrumento de los poderes. Hace más útil nuestra sensibilidad ante las diferencias, y fortalece nuestra capacidad de soportar lo inconmensurable. No encuentra su razón en la homología de los expertos, sino en la paralogía de los inventores ${ }^{14}$. 


\section{4.- De la Estética del Simulacro a la Incautación de lo Real}

El "ser" ya no cuenta, el valor deviene en "parecer"15, lo que se conoce como la "cultura del simulacro"16.

Los escritos de Baudrillard ${ }^{17}$, otro de los profetas de la posmodernidad, tributan a una obsesión por el signo y sus espejos, el signo y su producción febril en la sociedad de consumo, la virtualidad del mundo y La transparencia del mal ${ }^{18}$. La mercancía y la sociedad contemporánea están consumidas por el signo, por un artefacto que suplanta y devora poco a poco lo real, hasta hacerlo subsidiario. Lo real existe por voluntad del signo, el referente existe porque hay un signo que lo invoca. Vivimos en un universo extrañamente parecido al original -las cosas aparecen replicadas por su propia escenificación- señala Baudrillard.

La Posmodernidad, en contraste con la Modernidad, se caracteriza por las siguientes notas: nihilismo y escepticismo, reivindicación de lo plural y lo particular, deconstrucción, relación entre hombres y cosas cada vez más mediatizada, lo que implica una desmaterialización de la realidad (Lyotard). Con respecto a esto Jean Baudrillard habla de un "asesinato de la realidad". En su libro El crimen perfecto, presenta metafóricamente cómo se produce en las postrimerías de siglo esta desaparición de la realidad mediante la proliferación de pantallas e imágenes, transformándola en una realidad meramente virtual: "Vivimos en un mundo en el que la más elevada función del signo es hacer desaparecer la realidad, y enmascarar al mismo tiempo esa desaparición".

No existe ya la posibilidad de una mirada, de una mirada de aquello que suscita la mirada, porque, en todos los sentidos del término, aquello otro ha dejado de mirarnos. El mundo ya no nos piensa, Tokio ya no nos quiere ${ }^{19}$. Si ya no nos mira, nos deja completamente indiferentes. De igual forma el arte se ha vuelto por completo indiferente a sí mismo en cuanto pintura, en cuanto creación, en cuanto ilusión más poderosa que lo real. No cree en su propia ilusión, y cae irremediablemente en el absurdo de la simulación de sí mismo.

Baudrillard intuye la evolución de fin de milenio como una anticipación desesperada y nostálgica de los efectos de desrealización producidos por las tecnologías de comunicación. Anticipa el despliegue progresivo de un mundo en el que toda posibilidad

15 Jean BAUDRILLARD establece la diferencia entre disimular y simular. Lo primero es fingir no tener lo que se tiene. Quien disimula, intenta pasar desapercibido. Pero quien simula, aparenta ser quien no es, o poseer lo que no tiene; busca crear una imagen de algo inexistente. El disimulo no cambia la realidad, sólo la oculta o enmascara, en cambio la simulación muestra como verdadero algo que no lo es. Uno remite a una presencia, lo otro a una ausencia, a una nada. Ahora el problema actual es la simulación, concluye BAUDRILLARD. De este modo Ahora el simulacro produce una disociación entre lo que se muestra y la realidad, entre el ser y el parecer.

16 LIPOVETSKY, Gilles. (1992), El crepúsculo del deber. La ética indolora de los nuevos tiempos democráticos, Anagrama. Colección Argumentos: Barcelona, 1996

17 VÁSQUEZ ROCCA, Adolfo, "Baudrillard; de la metástasis de la imagen a la incautación de lo real", En EIKASIA. Revista de Filosofía, OVIEDO, ESPAÑA. ISSN 1885-5679, año II, No 11 (julio 2007 ) pp. 53-59. http://www.revistadefilosofia.com/11-02.pdf

18 BAUDRILLARD, Jean, La transparencia del mal, Ed. Anagrama, Barcelona, 2001

19 LORIGA, Ray, Tokio ya no nos quiere, Plaza \& Janes. Colección Ave Fénix. Barcelona, 1999. 
de imaginar ha sido abolida. El feroz dominio integral del imaginario sofoca, absorbe, anula la fuerza de imaginación singular.

Baudrillard localiza precisamente en el exceso expresivo el núcleo esencial de la sobredosis de realidad. Ya no son la ilusión, el sueño, la locura, la droga ni el artificio los depredadores naturales de la realidad. Todos ellos han perdido gran parte de su energía, como si hubieran sido golpeados por una enfermedad incurable y solapada20. Lo que anula y absorbe la ficción no es la verdad, así como tampoco lo que deroga el espectáculo no es la intimidad; aquello que fagocita la realidad no es otra cosa que la simulación, la cual secreta el mundo real como producto suyo.

Baudrillard exhausto de la esperanza del fin certifica que el mundo ha incorporado su propia inconclusibilidad. La eternidad inextinguible del código generativo, la insuperabilidad del dispositivo de la réplica automática, la metáfora viral ${ }^{21}$. La extinción de la lógica histórica ha dejado el sitio a la logística del simulacro y ésta es, según parece, interminable.

El momento postmoderno es, como se ve, un momento antinómico, en el que se expresa una voluntad de desmantelamiento, una obsesión epistemológica con los fragmentos o las fracturas, y el correspondiente compromiso ideológico con las minorías políticas, sexuales o lingüísticas.

Es necesario, a este respecto, tener presente que en la expresión "momento postmoderno" la palabra momento ha de tomarse literalmente22 - como un parpadeo, como un "abrir y cerrar de ojos" y, por decirlo paradójicamente, como categoría fundamental de una conciencia de época, claramente posthistórica.

La complejidad del momento postmoderno no es sólo una cuestión de perspectiva histórica -o más bien de falta de ella-, sino que viene dada por el propio movimiento de repliegue sobre sí mismo característico de la posmodernidad (frente a los desarrollos lineales de la periodización moderna o clásica) lo que la dota de un espacio histórico informe y desestructurado donde han caído los ejes de coordenadas, a partir de los cuales se establecía el sentido y el discurso de la escena histórico-cultural de una época.

La caída de los discursos de legitimación que vertebraban los diferentes meta-relatos de carácter local y dependiente, ha producido -como se ha señalado - una nivelación en las jerarquías de los niveles de significación y la adopción de prácticas inclusivistas e integradoras de discursos adyacentes, paralelos e incluso antagónicos.

La posmodernidad es aquel momento en que las dicotomías se difuminan y lo apócrifo se asimila con lo oficial.

Desde un determinado punto de vista, la "revolución de la posmodernidad" aparece como

20 BAUDRILLARD, Jean, Cultura y simulacro, Ed. Kairós, Barcelona, 1993

21 VÁSQUEZ ROCCA, Adolfo, "W. Burroughs; La metáfora viral y sus mutaciones antropológicas" En Almiar MARGEN CERO, Revista Fundadora de la ASOCIACIÓN DE REVISTAS DIGITALES DE ESPAÑA $\mathrm{N}^{\circ} 46$ - 2009. http://www.margencero.com/articulos/new03/burroughs.html

'Augenblick' puede traducirse como parpadeo, "abrir y cerrar de ojos". 
un gigantesco proceso de pérdida de sentido que ha llevado a la destrucción de todas las historias, referencias y finalidades. En el momento postmoderno el futuro ya ha llegado, todo ha llegado ya, todo está ya ahí. No tenemos que esperar ni la realización de una utopía ni un final apocalíptico. La fuerza explosiva ya ha irrumpido en las cosas. Ya no hay nada que esperar. Lo peor, el soñado final sobre el que se construía toda utopía, el esfuerzo metafísico de la historia, el punto final, está ya entre nosotros. Según esto, la posmodernidad sería una realidad histórica-posthistórica ya cumplida, y la muerte de la modernidad ya habría hecho su aparición.

En este sentido, el artista postmoderno se encuentra en la misma situación de un filósofo: el texto que escribe, la obra que compone, no se rigen en lo fundamental por reglas ya establecidas, no pueden ser juzgadas según un canon valorativo, esto es, según categorías ya conocidas. Antes bien, son tales reglas y categorías lo que el texto o la obra buscan. De modo que artista y escritor trabajan sin reglas, trabajan para establecer las reglas de lo que habrá llegado a ser. La negación progresiva de la representación se vuelve aquí sinónimo de la negación de las reglas establecidas por las anteriores obras de arte, que cada nueva obra ha de llevar a cabo de nuevo.

Todo esto ya se encuentra prefigurado en las vanguardias artísticas de comienzo del siglo pasado.

\section{5.- Del metarelato a la Posmodernidad estética; discurso y producción}

Ahora bien, el postmodernismo como ideología puede ser entendido como un síntoma de los cambios estructurales más profundos que tienen lugar en nuestra sociedad y su cultura como un todo o, dicho de otra manera, en el modo de producción.

Esta constatación del modo diferente de construcción de la realidad va seguida de la distinción entre una estetización "superficial" y una profunda: la primera refiere a fenómenos globales como el embellecimiento de la realidad, lo cosmético y el hedonismo como nueva matriz de la cultura y la estetización como estrategia económica; el segundo incluiría las transformaciones en el proceso productivo conducidas por la nuevas tecnologías y la constitución de la realidad por los medios de comunicación. Dentro de este escenario global es que debe analizarse lo que ha estado gestándose en los últimos doscientos años, nos referimos a la "estetización epistemológica" o como he querido llamarlo23 el giro estético de la epistemología24. Este se inicia con el establecimiento de la estética como disciplina epistemológica basal, que pasa por la configuración nietzscheana del carácter estético-ficcional del conocimiento y termina en el siglo XX con la estetización epistemológica que puede rastrearse en la nueva filosofía analítica y el establecimiento de la hermenéutica - las interpretación que dota de sentido a los hechos como ciencia central de la Posmodernidad, de allí que surjan como categorías

23 VÁSQUEZ ROCCA, Adolfo, "La ficción como conocimiento, subjetividad y texto"; de Duchamp a Feyerabend, En Psikeba Revista de Psicoanálisis y Estudios Culturales, No 1- 2006, Buenos Aires.

24 VÁSQUEZ ROCCA, Adolfo, "El Giro Estético de la Epistemología; La ficción como conocimiento, subjetividad y texto", En Revista AISTHESIS, INSTITUTO DE ESTÉTICA, PONTIFICIA UNIVERSIDAD CATÓLICA DE CHILE, PUC, No. 40, 2006 , pp. 4561.http://www.puc.cl/estetica/html/revista/pdf/Adolfo Vssquez.pdf 
fundamentales - en el modo de hacer filosofía - el texto y el discurso. Con Gadamer la Hermenéutica cobra un nuevo giro, ya no pretende aprehender el verdadero y único sentido del texto, sino manifestar las diversas interpretaciones del texto y las diversas formas de interpretar. Hemos aludido por primera vez a un elemento fundamental del pensamiento postmoderno: el texto.

La Posmodernidad, si la entendemos como Filosofía del Lenguaje, es una reflexión sobre el lenguaje escrito, en contraposición con la tendencia anglosajona que se centra en el lenguaje oral. El texto se independiza del autor hasta tal punto de que el autor puede ser obviado. El texto se independiza de su autor, porque con cada lectura tiene lugar una reelaboración, que es en sí misma una reinterpretación; no tiene sentido intentar encontrar lo que el autor ha querido decir, sino lo que los lectores, a lo largo de la historia, han dicho que el texto quería decir. La verdad se transforma en verdad interpretativa o verdad hermenéutica.

\section{6.- Deconstrucción de la noción de "autor"}

La noción de "autor" -como creador individual de una obra artística o literaria- se puede situar histórica y culturalmente en el tránsito de la modernidad a la posmodernidad, la noción de creador individual empieza a problematizarse desde fines del siglo XIX y a lo largo del siglo XX, donde la noción se hace insostenible.

Tal como lo refiere Michel Foucault, el autor que desde el siglo XIX venía jugando el papel de regulador de la ficción, papel característico de la era industrial y burguesa, del individualismo y de la propiedad privada, habida cuenta de las modificaciones históricas posteriores, no tuvo ya ninguna necesidad de que esta función permaneciera constante en su forma y en su complejidad.

Para Foucault el autor es una producción cultural que mediante la experiencia de una subjetividad replegada sobre sí -fragmentada- da lugar al yo individual, a la personalidad que difumina la conciencia de pertenecer a un colectivo. Así, la pérdida de la experiencia colectiva modifica la noción misma de relato y con ello el sentido colectivo de la escritura, esto es, como memoria e inconsciente que se escribe.

De este modo se intentará abolir al autor, así como a cualquier otra forma de institucionalización de la escritura. Por ello el discurso no será considerado más que en sus descentramientos y sus desterritorializaciones. Al dar por cierta la desaparición del sujeto, el discurso que funda la subjetividad no puede mantener los mismos niveles de coherencia más que como una forma de ejercer poder.

Todas las operaciones que designan y asignan las obras deben ser consideradas siempre como operaciones de selección y de exclusión. "Entre los millones de huellas dejadas por alguien tras su muerte, ¿cómo se puede definir una obra?". Responder la pregunta requiere una decisión de separación que distingue (de acuerdo con criterios que carecen tanto de estabilidad como de generalidad) los textos que constituyen la "obra" y aquellos que forman parte de una escritura o una palabra "sin cualidades" y que, por ende, no han de ser asignados a la "función de autor". 
Debe considerarse además que estas diferentes operaciones -delimitar una obra (un corpus), atribuirla a un autor, producir su comentario- no son operaciones neutras. Ellas están orientadas por una misma función, definida como "función restrictiva y coercitiva" que apunta a controlar los discursos clásicos, ordenándolos y distribuyéndolos.

Tal como lo refiere Michel Foucault, el autor que desde el siglo XIX venía jugando el papel de regulador de la ficción, papel característico de la era industrial y burguesa, del individualismo y de la propiedad privada, habida cuenta de las modificaciones históricas posteriores, no tuvo ya ninguna necesidad de que esta función permaneciera constante en su forma y en su complejidad.

Como sucesor del autor, el escritor ya no tiene pasiones, humores, sentimientos, impresiones, sino un rol bifurcador de discursos propios y ajenos, en una intertextualidad que prolifera hasta perder los lindes del yo, hasta la escisión de la identidad o su fragmentación esquizoide en la escritura.

La muerte del autor responde, de este modo, al proyecto de desubjetivación, que intenta eliminar la referencia a un sujeto originario sustentador de la verdad y el sentido del texto. En efecto, el sujeto que comienza a pensarse en la escritura, es un sujeto deudor de las citas de la cultura que tejen su obra. El entramado que constituye al texto posee una referencialidad infinita, que multiplica desde distintas vertientes elementos refractarios de otras. Aquello que preexiste de trasfondo es la muerte de un referente máximo que establezca los linderos -los alcances- de las miradas; es la proliferación de las perspectivas.

De este modo en el pensamiento contemporáneo ha tenido lugar un acoso sistemático a las nociones de sujeto y verdad, tal como la tradición científica y filosófica las concibió, decretando su expulsión de los reductos de la psicología, la historia, la antropología y la sociología. La pretensión de objetividad por parte de un sujeto que no puede sino ser contingente ha generado una serie de dudas y sospechas en torno a la noción misma de sujeto que sustenta los discursos científicos y filosóficos desde la modernidad.

Un planteamiento interesante en torno las relaciones conflictuadas entre autor, texto y lector, así como de la cuestión anteriormente planteada respecto de las nociones de autor y autoría, es la de Juan Luis Martínez. La propuesta del poeta es la de una autoría transindividual, que quiere superar desde oriente la noción de intertextualidad según se ha entendido en occidente, donde los textos de base están presentes en las transformaciones del texto que los procesa; pero en J. L. Martínez ésta [intertextualidad] parece resolverse en la negación de la existencia de las individualidades en la literatura, al hacer fluir bajo nombres distintos una misma corriente, que es y no es él. El ideario poético con el que J. L. Martínez aparece comprometido es el de emanar una identidad velada, en sus palabras "no sólo ser otro sino escribir la obra de otro". Fue Flaubert quien dijo que "un autor debe arreglárselas para hacer creer a la posteridad que no ha existido jamás". Palabras que calaron hondo en Juan Luís Martínez poeta secreto como pocos. El poeta debe saber andar sobre sus pasos y borrar sus propias huellas.

En la Posmodernidad hay dos tendencias muy marcadas y contradictorias sobre la autoría, la que la desprecia por centrarse únicamente en el texto y la que quiere explicar el texto como trasunto del autor. No cabe hablar propiamente de un autor, pues el autor 
del texto se ha perdido, como también se ha perdido el ser humano como sujeto, hoy son los sistemas de producción de signos los que reclaman para sí la atención y esto esta dado en lo que Debord llamará La Sociedad del Espectáculo, o Lipovetsky el Imperio de lo Efímero. De allí que fenómenos en apariencia banales como el el cine, la moda, el diseño y la arquitectura, entendidos éstos como sistemas productores de signos, o de narratividades -de acuerdo a su modo de constitución- influyen de manera decisiva en el modo de ser, en el ethos postmoderno, el cual puede ser entendido desde dentro de su proceso de gestación sólo a partir de las claves hermenéuticas que nos proporciona el paradigma estético.

\section{7.- Las obras de arte como organizaciones imaginarias del mundo}

Así Lyotard al utilizar los términos "relato", "grandes relatos" y "metarrelato" se dirige a un mismo referente: los discursos legitimadores a nivel ideológico, social, político y científico. "Un metarrelato es, en la terminología de Lyotard, una gran narración con pretensiones justificatorias y explicativas de ciertas instituciones o creencias compartidas." ${ }^{25}$ Un Léxico último -si se quiere emplear la terminología de Rorty-. El discurso legitimador se caracteriza no por ser prosa narrativa sino principalmente prosa argumentativa. Todo intento que realizar políticamente un sistema ideológico tienen en su interior el germen del totalitarismo, la determinación de la pluralidad a partir de un solo punto de vista que se impone por todos los medios posibles. En cambio, los microrelatos, las narraciones literarias -por ejemplo- no tienen la intención de dar cuenta de hechos verdaderos sino que su consistencia artística deriva de su verosimilitud, es decir, de la capacidad del texto para hacerse creíble dentro de su contexto y del mundo que ha creado.

De este modo las obras de arte no son, pues, objetos específicos -aislados del mundo y de su acontecer-, sino más bien organizaciones imaginarias del mundo, las que para ser activadas requieren ser puestas en contacto con un modo de vida, por particular que este sea, con un fenómeno concerniente al ser humano, de modo tal que, como se hace evidente en la posmodernidad, arte, producción y vida se codeterminan y se copertenecen.

El estallido de los grandes relatos es de este modo el instrumento de la igualdad y de la emancipación del individuo liberado del terror de los megasistemas, de la uniformidad de lo Verdadero, del derecho a las diferencias, a los particularismos, a las multiplicidades en la esfera del saber aligerado de toda autoridad suprema, de cualquier referencia de realidad. La operación del saber posmoderno, es la de la heterogeneidad y dispersión de los lenguajes al modo de Babel, de las teorías flotantes, todo lo cual no es más que una manifestación del hundimiento general -fluido (líquido) y plural- que nos hace salir de la edad disciplinaria y amplía la continuidad democrática e individualista que dibuja la originalidad del momento posmoderno, es decir el predominio de lo individual sobre lo universal, de lo psicológico sobre lo ideológico, de la comunicación sobre la politización , de la diversidad sobre la homogeneidad, de lo permisivo sobre lo coercitivo.

25 DIÉGUEZ, Antonio (2006). "La ciencia desde una perspectiva postmoderna: Entre la legitimidad política y la validez epistemológica". II Jornadas de Filosofía: Filosofía y política (Coín, Málaga 2004), Coín, Málaga: Procure, 2006, pp. 177-205. 
BIBLIOGRAFÍA:

- $\quad$ ANDERSON, Perry, Los orígenes de la posmodernidad. Anagrama. Madrid, 2000. ISBN 84-339-0591-0

- $\quad$ BAUDRILLARD, Jean (1995). La ilusión del fin. La huelga de los acontecimientos. Barcelona: Anagrama.

- $\quad$ BAUDRILLARD, Jean (1998). Cultura y simulacro. Barcelona: Kairós.

- BECK, Ulrich (1998). ¿Qué es la globalización? Falacias del globalismo, respuestas a la globalización. Barcelona: Paidós.

- $\quad$ BERGER, Peter; LUCKMANN, Thomas (1997). Modernidad, pluralismo y crisis de sentido. La orientación del hombre moderno. Barcelona: Paidós.

- DERRIDA, Jacques : Espectros de Marx: el Estado de la deuda, el trabajo del duelo y la nueva Internacional, Trotta, 1995.

- $\quad$ DEBORD, Guy, La sociedad del espectáculo, Editorial Pre-textos, Valencia 1999

- $\quad$ JAMESON, Fredric. Teoría de la posmodernidad. Madrid: Trotta, 1996.

- JAMESON, Fredric : El posmodernismo o la lógica cultural del capitalismo avanzado, Paidós, 1991.

- $\quad$ FOUCAULT, Michel, Las palabras y las cosas, Ed. Gallimard, París, 1966

- $\quad$ RICOEUR, Paul, Historia y narratividad, Editorial Paidós, Barcelona, 1999

- $\quad$ LIPOVETSKY, Gilles. La era del vacío. Barcelona, Anagrama: 1986.

- $\quad$ LIPOVETSKY, Gilles. (1992), El crepúsculo del deber. La ética indolora de los nuevos tiempos democráticos, Anagrama. Colección Argumentos: Barcelona, 1996

- $\quad$ LIPOVETSKY, Gilles, El imperio de lo efímero, Editorial Anagrama, Madrid, 1990.

- $\quad$ LYOTARD, Jean-François., La Condition Postmoderne. Paris: Minuit, 1979

- $\quad$ LYOTARD, Jean F. La condición postmoderna. Madrid: Cátedra S.A. 1987.

- $\quad$ LYOTARD, Jean F. La condición postmoderna. Buenos Aires: Teorema, 1989.

- VÁSQUEZ ROCCA, Adolfo, "El Giro Estético de la Epistemología; La ficción como conocimiento, subjetividad y texto", En Revista AISTHESIS, PUC, No. 40, 2006, pp. 45-61. http://www.puc.cl/estetica/html/revista/pdf/Adolfo Vssquez.pdf

- $\quad$ INNERARITY, Daniel, Dialéctica de la Modernidad, Ediciones Rialp, Madrid, 1990.

- HABERMAS, Jürgen, El discurso filosófico de la modernidad, en El pensamiento posmetafísico. Taurus. Madrid, 1990. ISBN 84-306-1300-5

- $\quad$ HABERMAS, Jürgen, El pensamiento postmetafisico, Editorial Taurus, Madrid, 1990 - $\quad$ HABERMAS, Jürgen (1991). Conciencia moral y acción comunicativa. Barcelona: Península.

- $\quad$ RUBERT DE VENTÓS, X. De la modernidad. Ensayo de filosofía crítica. Península. Barcelona, 1982. ISBN 84-297-1669-6

- KOSELLECK, Reinhart (1993). Futuro pasado. Contribución a la semántica de los tiempos históricos. Barcelona: Paidós.

- $\quad$ LYON, David (1996). Postmodernidad. Madrid: Alianza.

- $\quad$ LYOTARD, Jean-François (1989). La condición postmoderna. Informe sobre el saber. Madrid: Cátedra.

- $\quad$ LYOTARD, Jean-François, La condición posmoderna: Informe sobre el saber (La Condition postmoderne: Rapport sur le savoir. 1979). ISBN 84-376-0466-4

- LYOTARD, Jean-François (1995). La posmodernidad (explicada a los niños). Barcelona: Gedisa.

- $\quad$ VATTIMO, Gianni (1994). La sociedad transparente. Barcelona: Paidós. 
- $\quad$ G. VATTIMO, J. M. Mardones, I. Urdanabia... [et al.]. En torno a la posmodernidad. Anthropos. Barcelona. 1990. ISBN 84-7658-234-X

- $\quad$ SLOTERDIJK Peter, Critica de la razón cínica I y II, Madrid: Ed. Siruela, 2004.

- WELLMER, Albrecht, Sobre la Dialéctica de la modernidad y la posmodernidad, Editorial Visor, Madrid, 1993.

- ŽZŽEK, Slavoj : "Multiculturalismo o la lógica cultural del capitalismo multinacional", en Fredric Jameson y Slavoj Žižek: Estudios culturales. Reflexiones sobre el multiculturalismo, Paidós, 1998, págs. 137-188. 